\title{
Perancangan Sistem Pembayaran Elektronik Berbasis Radio Frequency Identification (RFID) pada Waserda Koperasi Karyawan PT Multi Karya Usaha
}

\author{
Teti Desyani \\ Program Studi Teknik Informatika, Universitas Pamulang \\ e-mail : tetidesyani@gmail.com
}

\begin{abstract}
Abstrak
Pemanfaatan perangkat elektronik dan komputer dalam sebuah usaha atau perusahaan sangat mendukung proses bisnis terhadap keuntungan yang di peroleh perusahaan, guna peningkatan keberhasilan bisnis perusahaan. Koperasi Karyawan PT. Multi Karya Usaha adalah koperasi yang dikelola oleh Karyawan PT. Multi Karya Usaha yang mempunyai unit usaha simpan pinjam dan warung serba ada (WASERDA) sebagai unit usaha unggulan nya. Setelah melakukan analisa, maka penulis menyimpulkan bahwa dalam sistem yang berjalan pada unit usaha waserdaKoperasi Karyawan PT Multi Karya Usaha memiliki beberapa masalah yaitu antrean saat transaksi penjualan, kesalahan pembuatan laporan transaksi dan kesulitan perekapan data laporan transaksi. Sehingga di butuhkan suatu sistem yang terkomputerisasi berbasis Radio Frequency Identification (RFID), untuk menangani masalah yang terjadi.Teknologi RFID akan digunakan sebagai alat pembayaran non tunai (e-money), dan untuk aplikasi nya dibangun menggunakan bahasa pemograman Visual Basic.Net dengan database SQL Server. Dengan adanya aplikasi ini, dalam proses pencarian, penginputan, dan pengolahan data serta transaksi yang berlangsung di dalam unit usaha waserda Koperasi Karyawan PT Multi Karya Usaha di harapkan akan lebih baik.
\end{abstract}

Kata kunci :RFID (Radio Frequency Identification), E-money, VB.Net, SQL Server

\section{Pendahuluan}

Koperasi merupakan sebuah badan usaha yang memiliki anggota dan setiap orangnya memliki tugas dan tanggung jawab masingmasing yang memiliki prinsip koperasi dan berdasar pada ekonomi rakyat sesuai dengan asas kekeluargaan yang tercantum pada Undang Undang Nomor 25 tahun 1992, pada era digital saat ini penggunaan sistem informasi berbasis teknologi elektronik telah merambah ke berbagai bidang transaksi, menurut williams dan sawyer pengertian teknologi informasi adalah teknologi yang menggabungkan komputasi (komputer) dengan jalur komunikasi kecepatan tinggi yang membawa data, suara, dan video.

Koperasi Karyawan PT. Multi Karya Usaha adalah koperasi yang dikelola oleh Karyawan PT. Multi Karya Usaha Provinsi Banten yang jumlah anggotanya 363 orang yang mempunyai unit kerja simpan pinjam dan warung serba ada (WASERDA). unit usaha warung serba ada (WASERDA) pada koperasi sudah merupakan usaha unggulan dan berada dibawah level unit simpan pinjam (USP).

Unit usaha warung serba ada (WASERDA) ditujukan sebagai unit usaha pelayanan untuk memenuhi kebutuhan sehari- hari bagi anggota. Dalam keberadaanya, perkembangan unit usaha warung serba ada (WASERDA) koperasi dihadapkan kepada beberapa persoalan yaitu, Pelanggan sering memberikan keluhan kepada pengurus koperasi tentang antrean yang ramai saat melakukan pembelian, Tidak ada informasi khusus yang menginformasikan tentang jumlah stok barang real time, sehingga pegawai baru mengetahui stok habis ketika proses transaksi penjualan berlangsung, Sering terjadi laporan pemasukan keuangan yang tidak sesuai antara barang yang terjual dan sisa stok, Proses perekapan data keuangan masih menggunakan prosedur yang panjang sehingga ketua koperasi dan pegawai lain nya tidak bisa mendapatkan laporan rekap data keuangan dengan cepat.

Untuk itu di butuhkan sebuah sistem kerja administrasi yang tertib, teratur dan, yang mana harus mempunyai sistem pencatatan dan pengarsipan data yang sistematis dan aman tentu nya transaksi yang mudah dan cepat. Hal ini hanya dapat dilakukan dengan memanfaatkan sistem informasi berbasis teknologi elektronik agar dapat menunjang kegiatan operasional dan memberikan layanan yang terbaik bagi anggota Koperasi karyawan PT. Multi Karya Usaha. 


\section{Metode Penelitian}

Prosedur sistem waserda dengan menggunakan Radio frequency identification (RFID)yang akan diusulkan adalah sebagai berikut:

a. Data Masukan meliputi:

1) Formulir master barang.

2) Formulir master supplier.

3) Formulir master anggota.

4) Formulir users access.

5) Formulir permission access.

6) Formulir register e-money.

7) Formulir top up e-money.

8) Formulir transaksi pembelian.

9) Formulir transaksi penjualan.

10) Fromulir transaksi stock opname.

b. Data Keluaran meliputi:

1) Laporan data barang.

2) Laporan data supplier.

3) Laporan data anggota.

4) Laporan riwayat transaksi e-money.

5) Laporan transaksi penjualan.

6) Laporan transaksi pembelian.

7) Laporan stock barang.

c. Aplikasi akan dipergunakan oleh:

1) Administrator, memiliki full hak akses yaitu form master users, permission access, mengelola semua formulir dan laporan yang ada dalam aplikasi.

2) Petugas waserda, memiliki hak akses yaitu form transaksi penjualan, form transaksi pembelian, from top up $e$ money, laporan riwayat transaksi $e$ money, laporan transaksi pembelian, dan laporan transaksi penjualan.

3) Bendahara, memiliki hak akses yaitu form master barang, form master supplier, form register e-money, laporan riwayat transaksi e-money, laporan transaksi pembelian, laporan transaksi penjualan, form transaksi stock opname.

4) Sekretaris, memilik hak akses yaitu form master anggota, laporan transaksi pembelian, laporan transaksi penjualan, form transaksi stock opname.

5) Ketua koperasi , memiliki hak akses yaitu laporan transaksi penjualan, laporan transaksi pembelian, laporan data master anggota, laporan data master supplier, laporan data master barang, laporan riwayat transaksi $e$ money.

\subsection{Use Case Diagram}

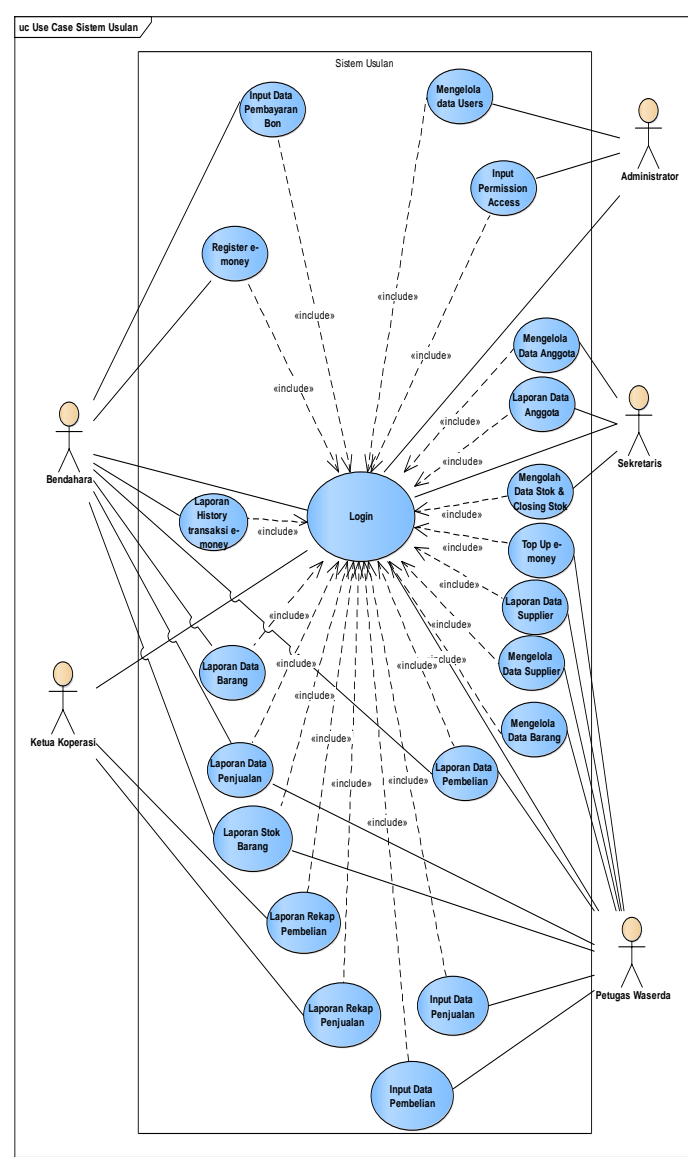

Gambar 1 Use Case Usulan

\subsection{Activity Diagram}

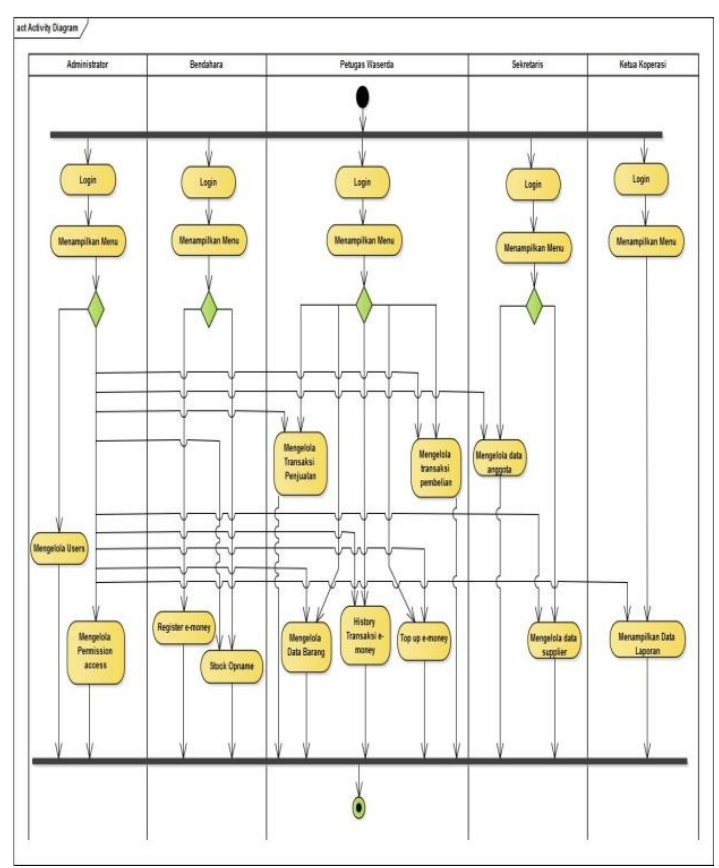

Gambar 2 Activity Diagram Usulan 


\subsection{Squence Diagram}

a. Sequence Diagram Login

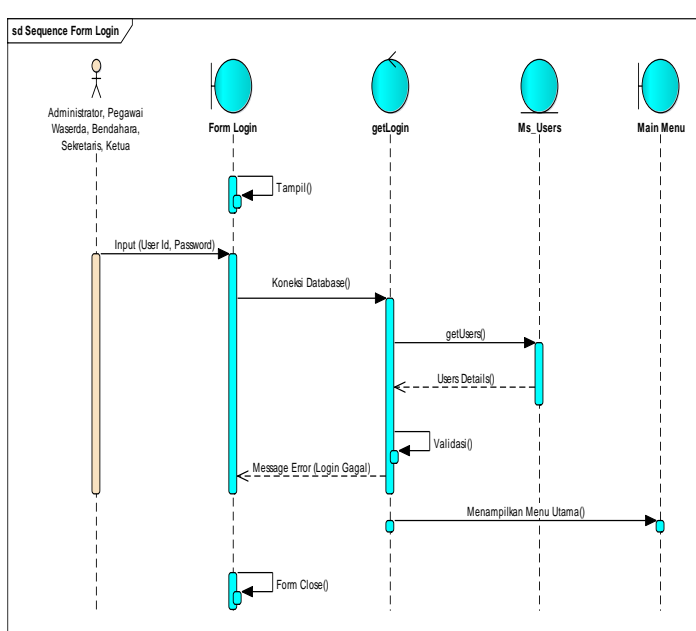

Gambar 3 Sequence Diagram Login

b. Sequence Diagram Main Menu

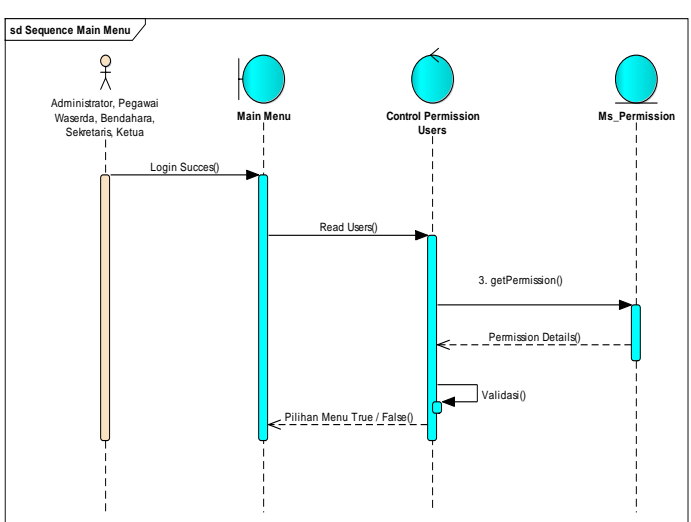

Gambar 4 Sequence Diagram Main Menu

c. Sequence Diagram Master Anggota

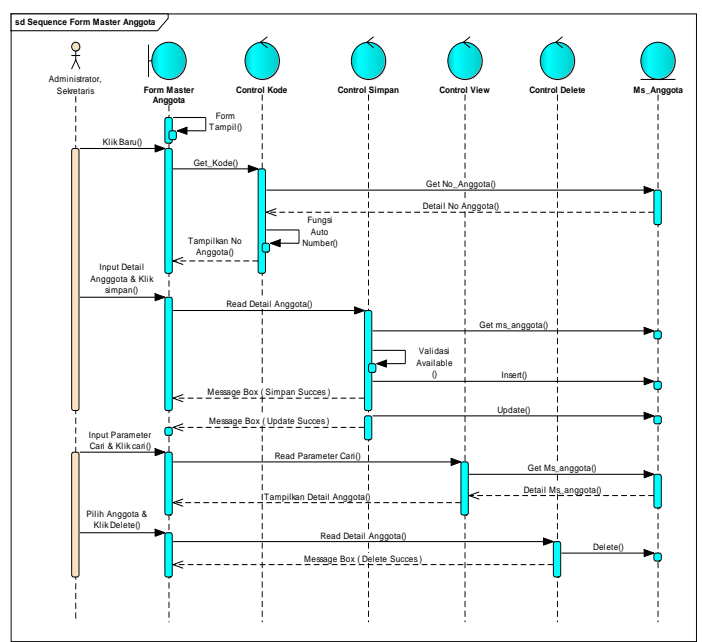

Gambar 5 Sequence Diagram Master Anggota d. Sequence Diagram Master Barang

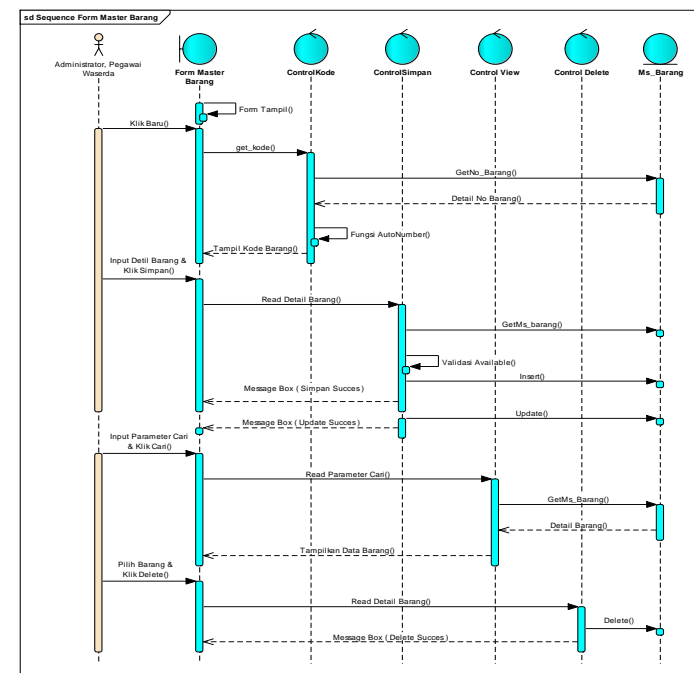

Gambar 6 Sequence Diagram Master Barang

e. Sequence Diagram Master Supplier

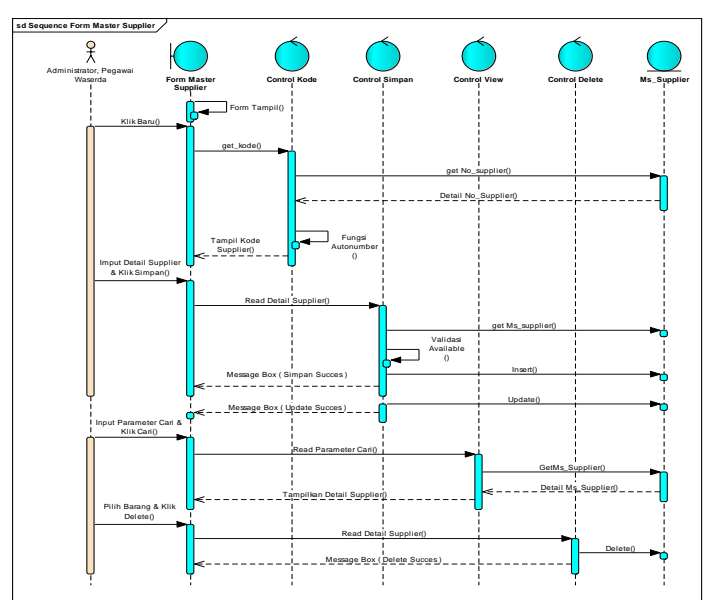

Gambar 7 Sequence Diagram Master Supplier

f. Sequence Diagram Form Pembelian

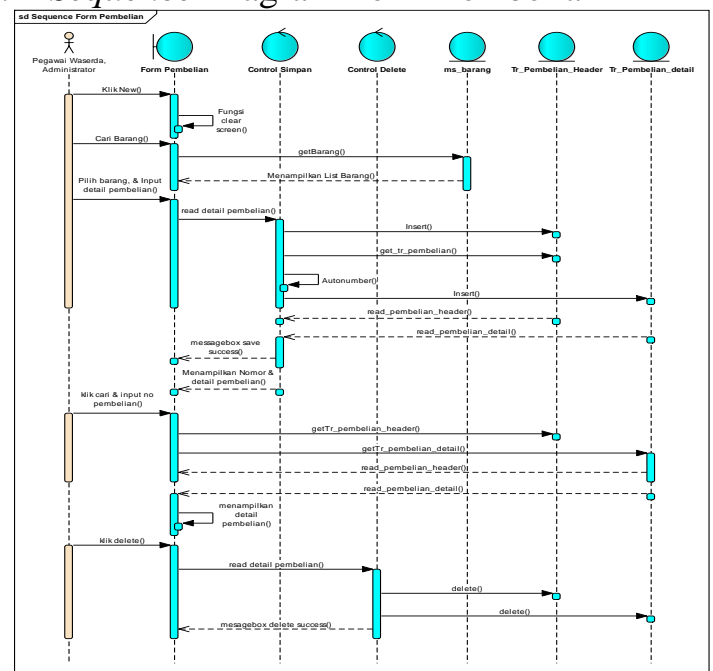

Gambar 8 Sequence Diagram Form Pembelian 
g. Sequence Diagram Form Penjualan

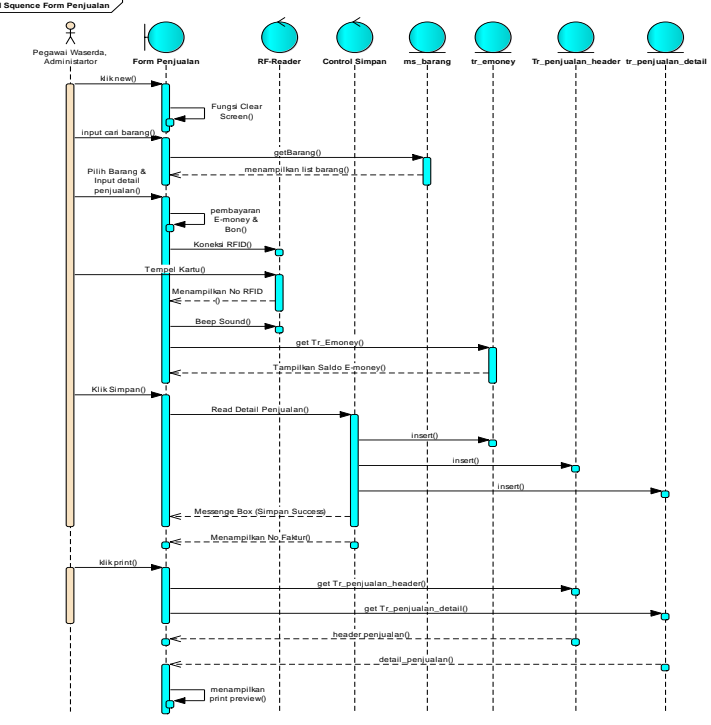

Gambar 9 Sequence Diagram Form Penjualan

h. Sequence Diagram Form Register E-money

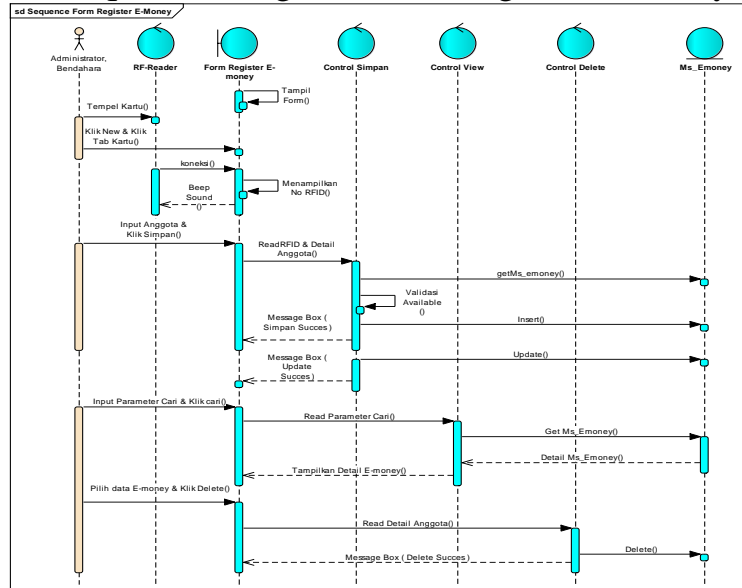

Gambar 10 Sequence Diagram Form Register Emoney

i. Sequence Diagram Form Pembayaran

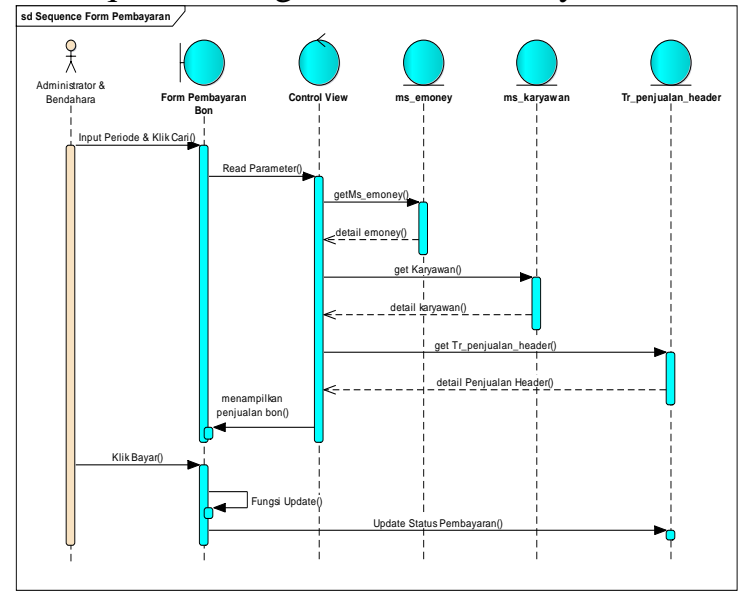

Gambar 11 Sequence Diagram Form Pembayaran j. SequenceDiagram Form Top Up E-money

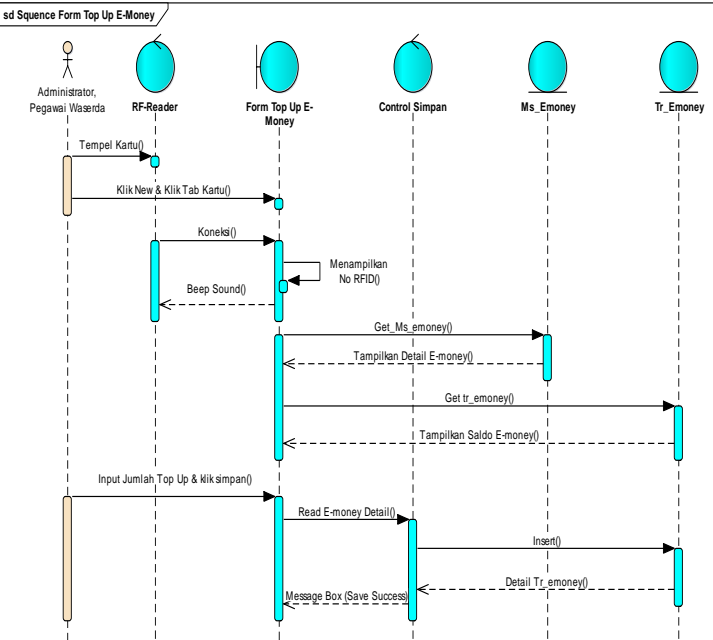

Gambar 12 Sequence Diagram Form Top Up Emoney

k. SequenceDiagram Form Riwayat Transaksi E-money

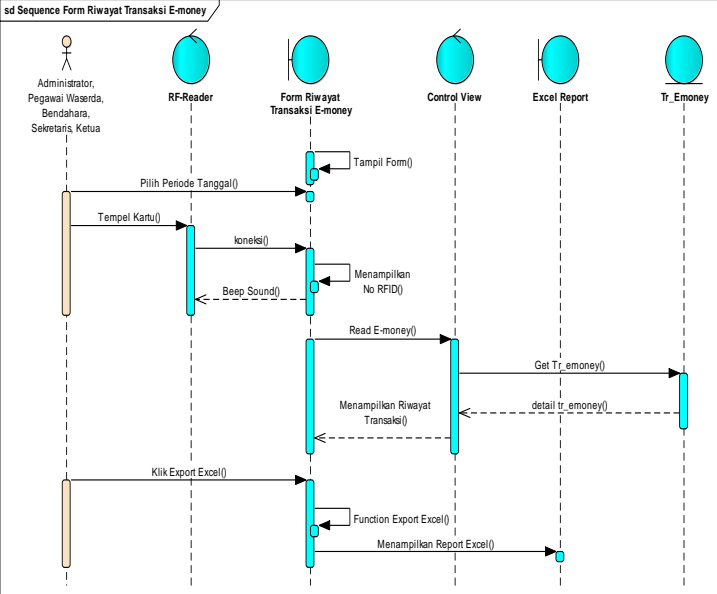

Gambar 13 Sequence Diagram Form Riwayat Transaksi E-money

1. SequenceDiagram Form Stock Opname

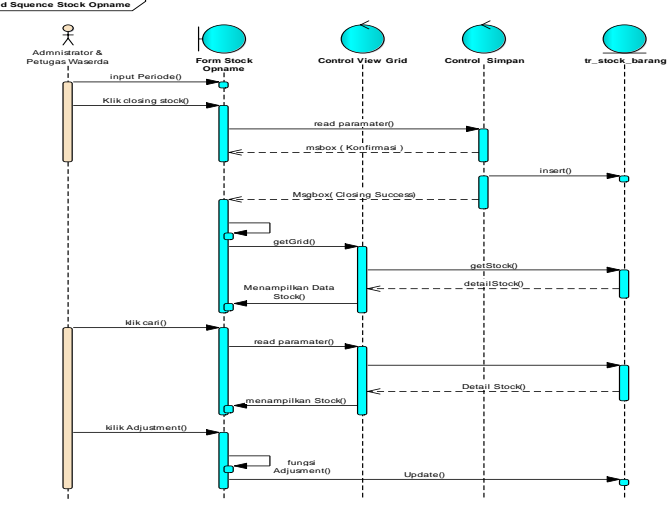

Gambar 14 Sequence Diagram Form Stock Opname 
m. Sequence Diagram Form Laporan Anggota

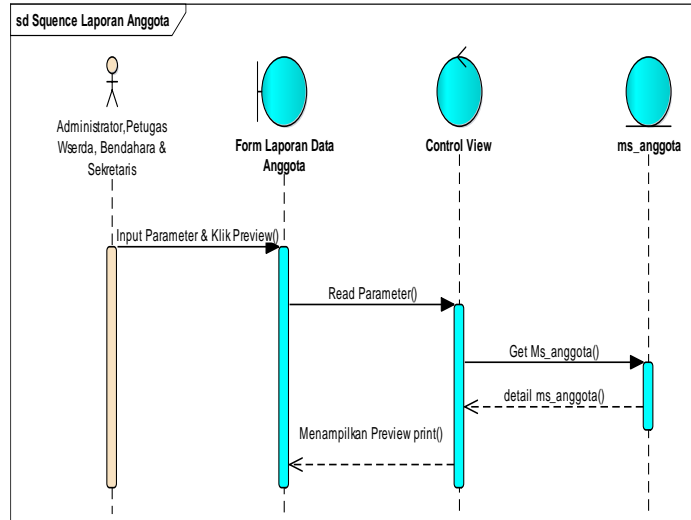

Gambar 15 Sequence Diagram Form Laporan Anggota

n. Sequence Diagram Form Laporan Barang

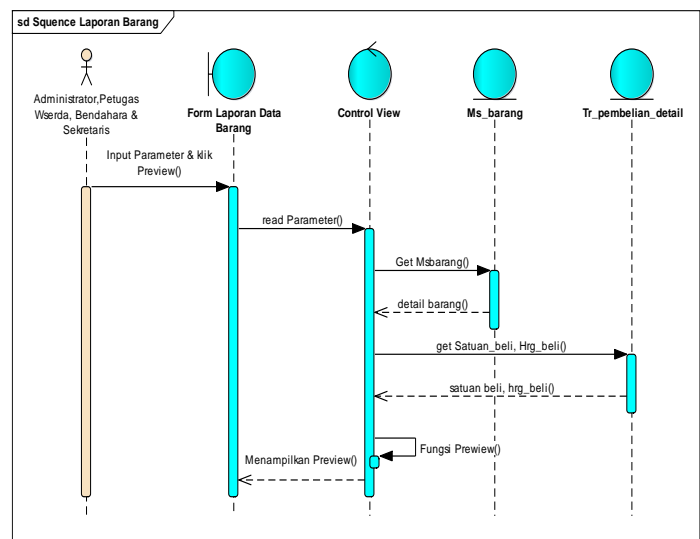

Gambar 16 Sequence Diagram Form Laporan Barang

o. Sequence Diagram Form Laporan Data Penjualan

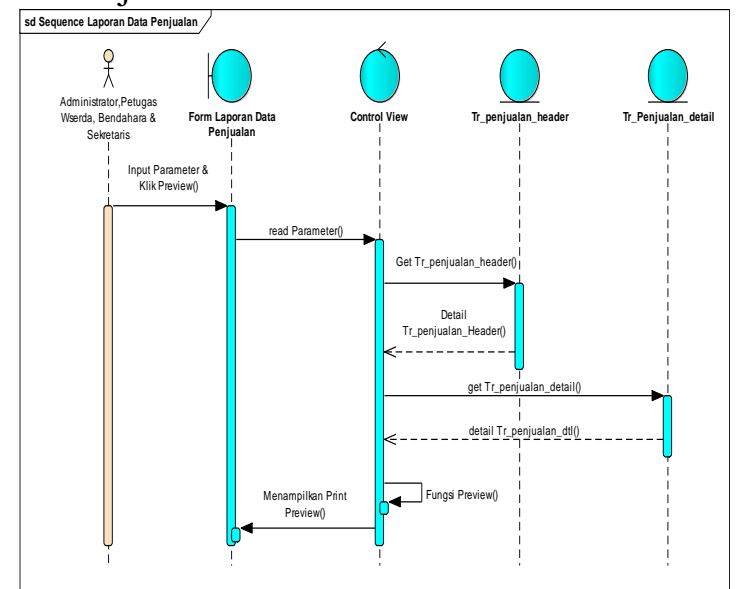

Gambar 17 Sequence Diagram Form Data Penjualan p. Sequence Diagram Form Laporan Data Pembelian

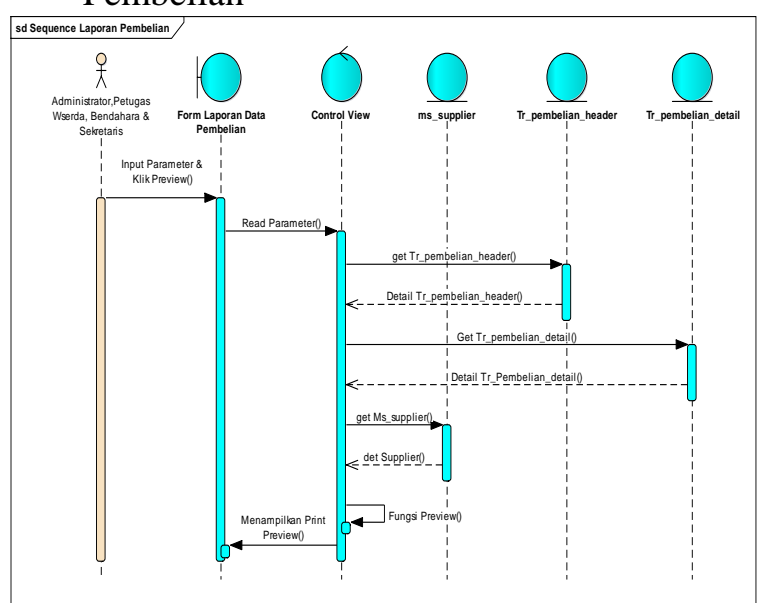

Gambar 18 Sequence Diagram Form Data Pembelian

q. Sequence Diagram Form Laporan Data Stock

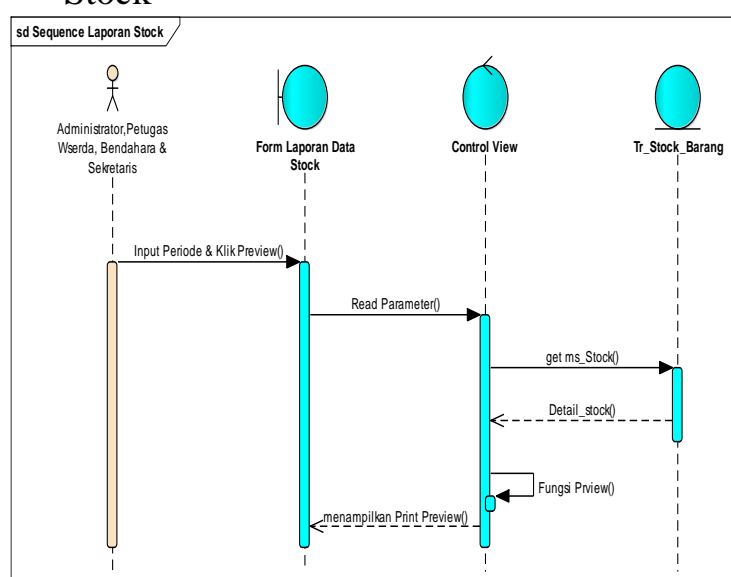

Gambar 19 Sequence Diagram Form Laporan Data Stock

r. Sequence Diagram Form Laporan Supplier

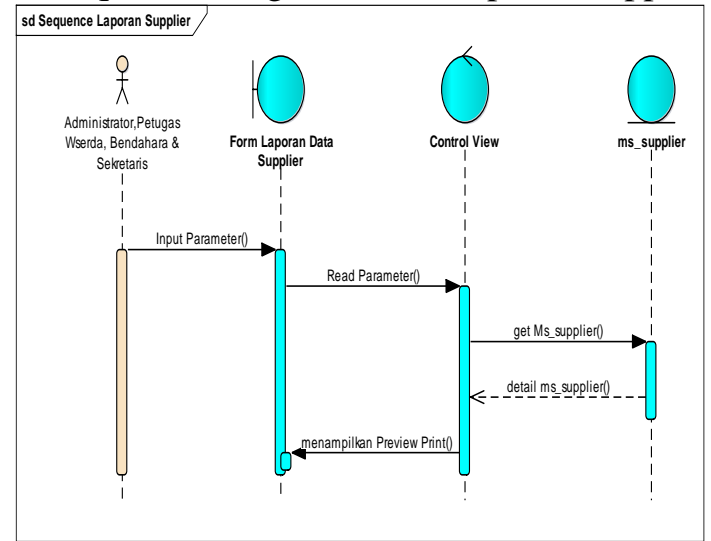

Gambar 20 Sequence Diagram Form Laporan Supplier 
s. Sequence Diagram Laporan Summary Pembelian

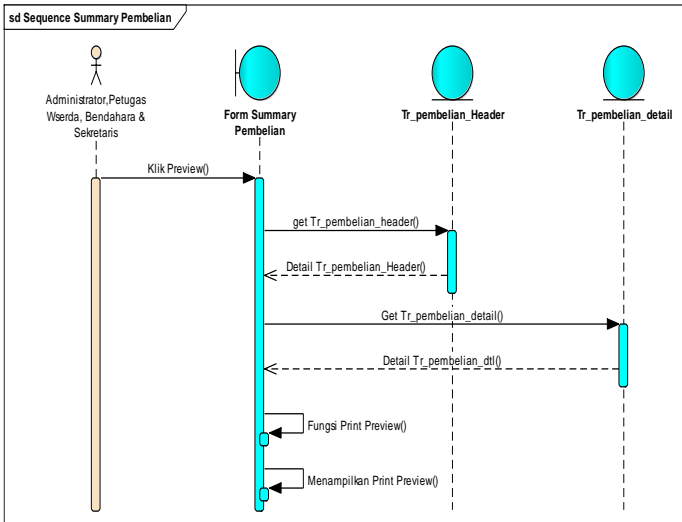

Gambar 21 Sequence Diagram Laporan Summary Pembelian

t. Sequence Diagram Diagram Summary Penjualan

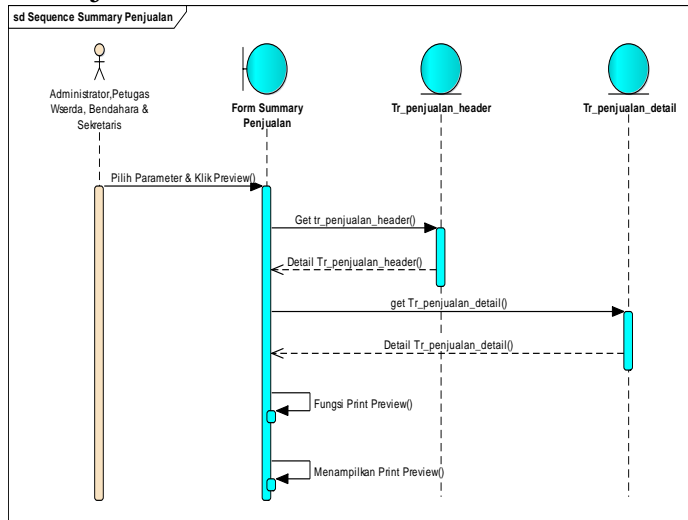

Gambar 22 Sequence Diagram Summary Penjualan

\section{Pembahasan}

\subsection{Tampilan Login}

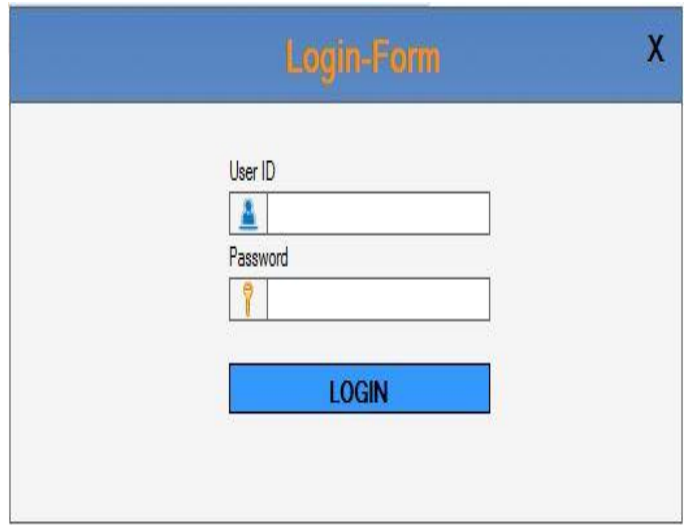

Gambar Tampilan Form Login

\subsection{Tampilan Form Menu Utama}

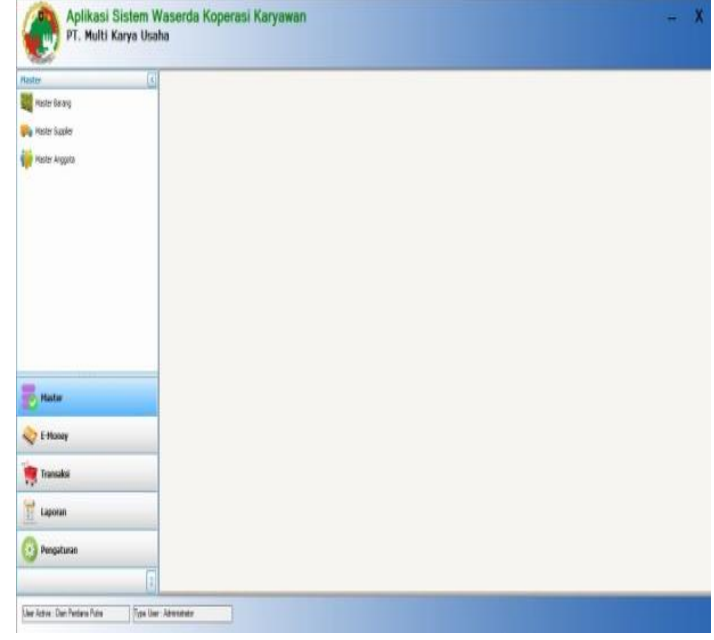

Gambar Tampilan Form Menu Utama

\subsection{Tampilan Form Master Barang}

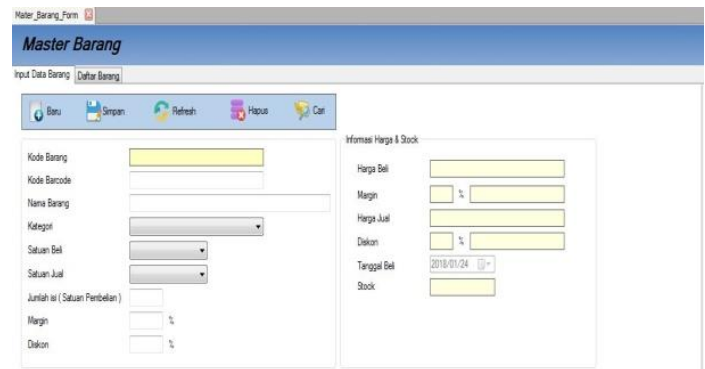

Gambar Tampilan Form Master Barang

\subsection{Tampilan Master Supplier}

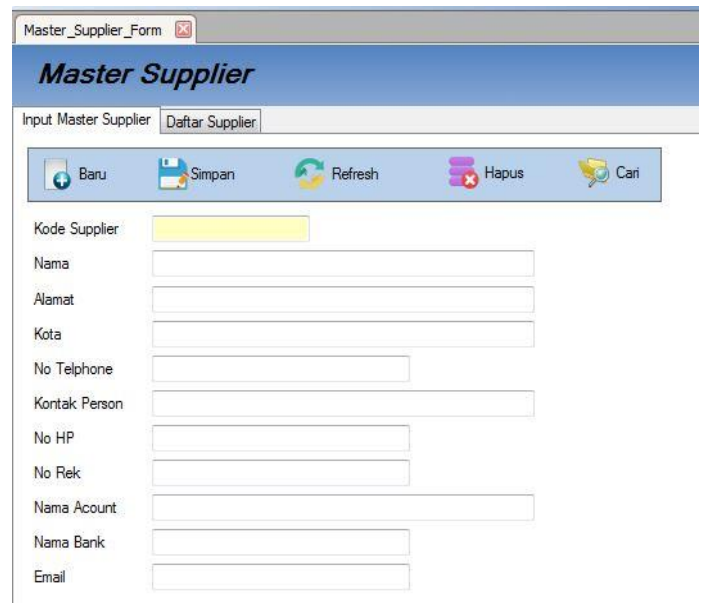

Gambar Tampilan Form Master Supplier 


\subsection{Tampilan Form Master Anggota}

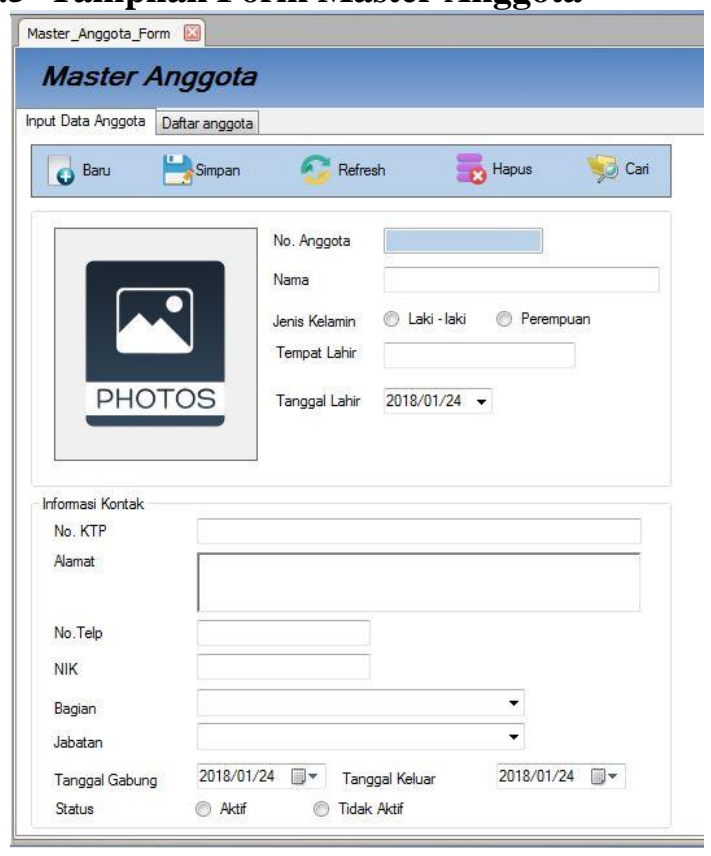

Gambar Tampilan Form Master Anggota

\subsection{Tampilan Form Register E-Money}

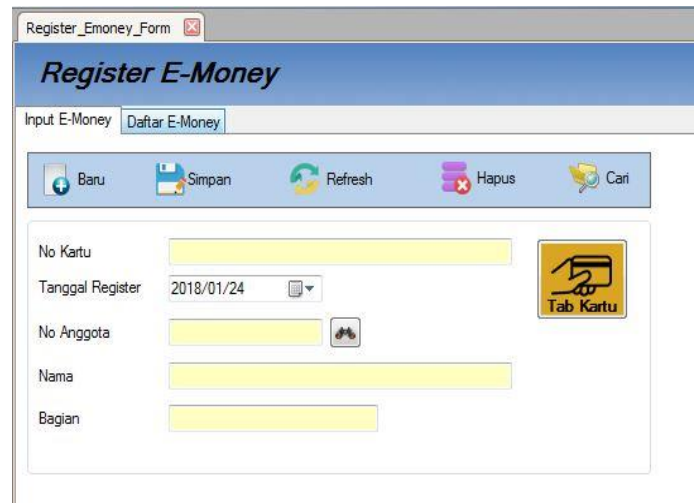

Gambar Tampilan Form Register E-Money

\subsection{Tampilan Form Top-up E-Money}

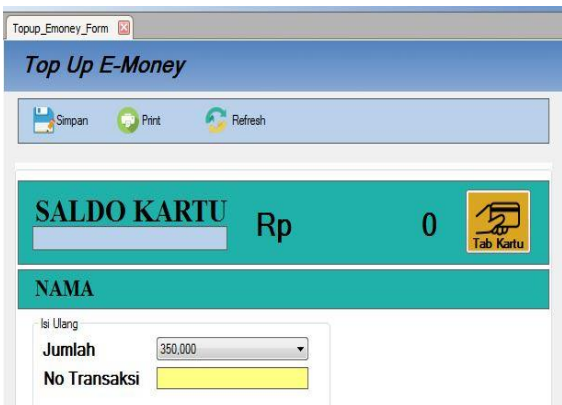

Gambar Tampilan Form Top Up E-Money
3.8 Tampilan Input Form Riwayat Transaksi E-Money

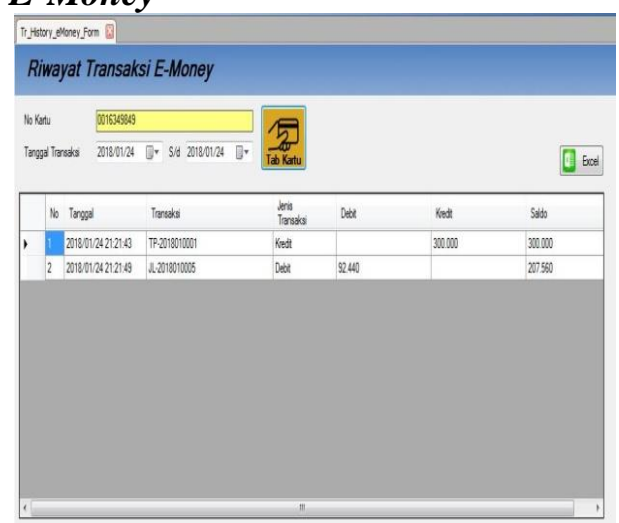

Gambar Tampilan Form Riwayat Transaksi $E$ money

\subsection{Tampilan Form Transaksi Pembelian}

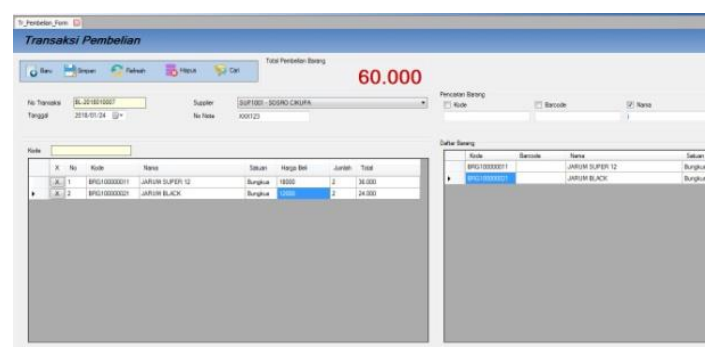

Gambar Tampilan Form Transaksi Pembelian

\subsection{Tampilan Form Transaksi Penjualan}

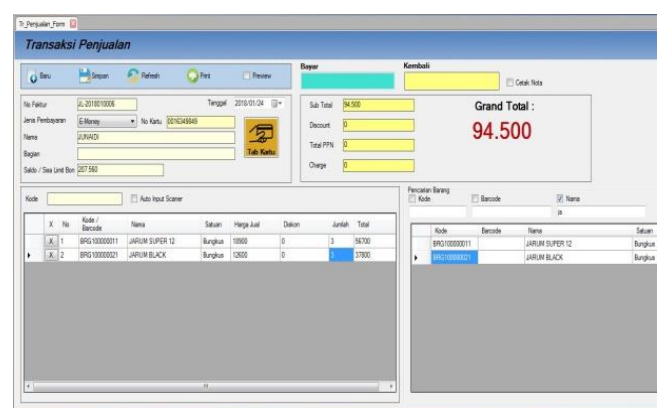

Gambar 10 Tampilan Form Transaksi Penjualan

\subsection{Tampilan Form Transaksi Stock Opname}

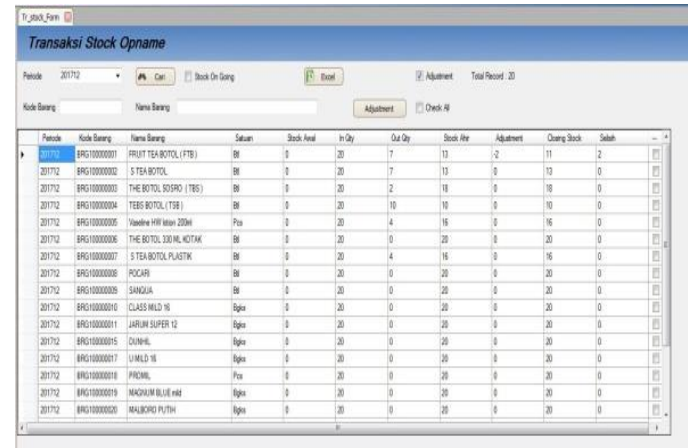

Gambar 11 Tampilan Form Stock Opname 


\subsection{Tampilan Form Transaksi Pembayaran Bon}

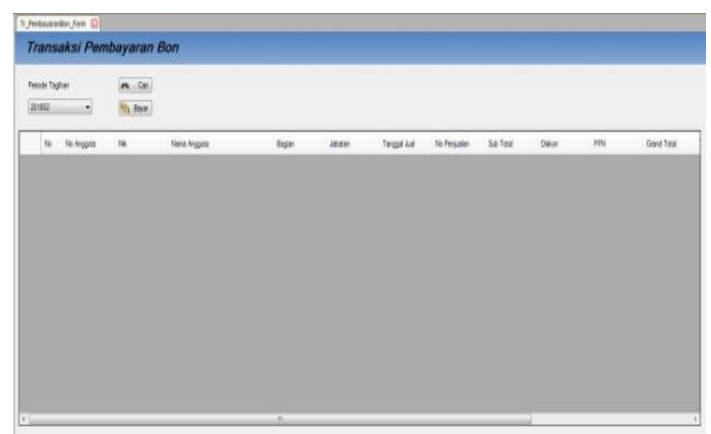

Gambar Tampilan Transaksi Pembayaran Bon

\subsection{Tampilan Form Laporan Data Barang}

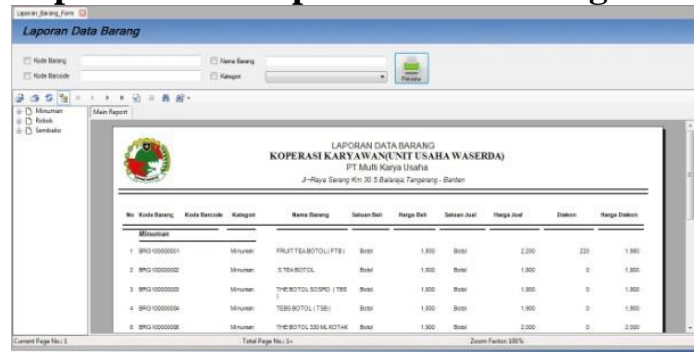

Gambar Tampilan Form Data Barang

\subsection{Tampilan Form Laporan Data Anggota}

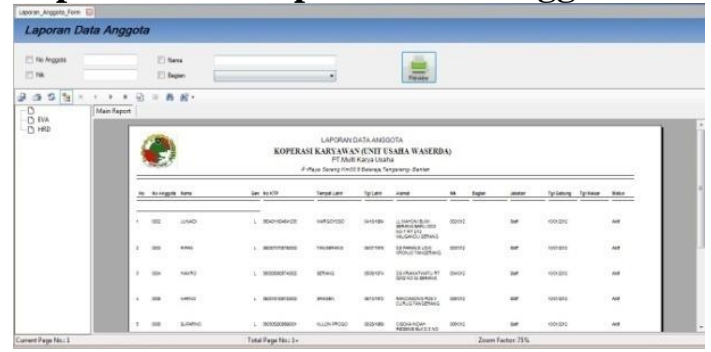

Gambar Tampilan Form Laporan Data Anggota

\subsection{Tampilan Form Laporan Data Supplier}

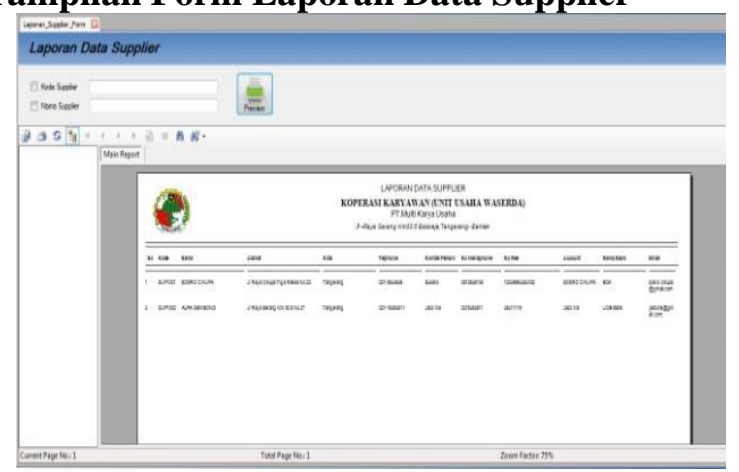

Gambar Tampilan Form Laporan Data Supplier

\subsection{Tampilan Form Laporan Data Pembelian}

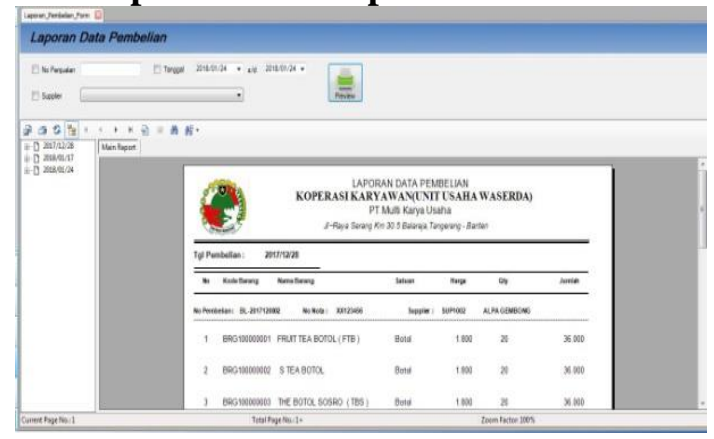

Gambar Tampilan Laporan Data Pembelian

\subsection{Tampilan Form Laporan Data Penjualan}

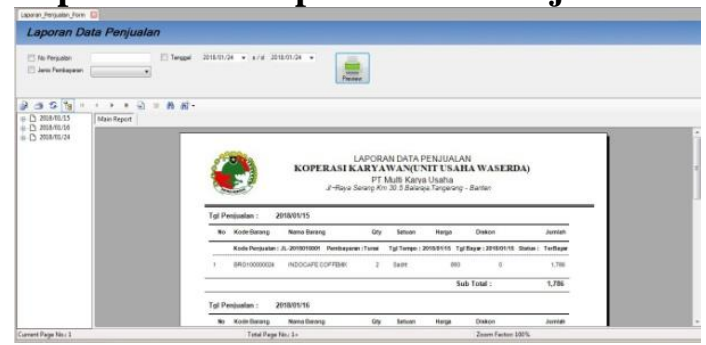

Gambar Tampilan Form Laporan Data Penjualan

\subsection{Tampilan Form Laporan Stock Barang}

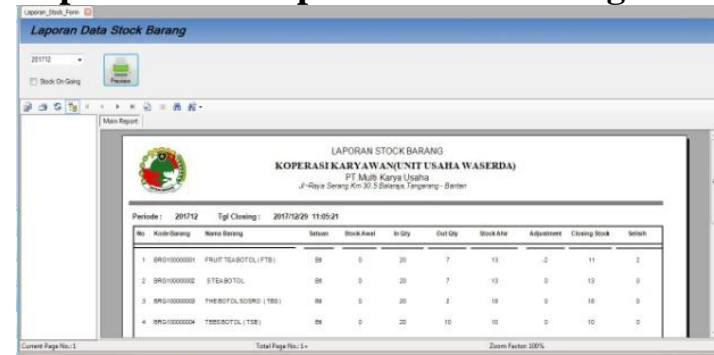

Gambar Tampilan Laporan Stock Barang

\subsection{Tampilan Form Laporan Rekap Pembelian}

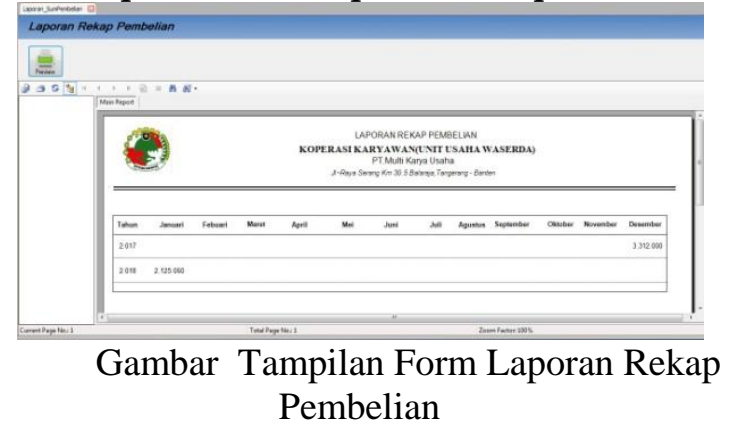




\subsection{Tampilan Form Laporan Rekap} Penjualan

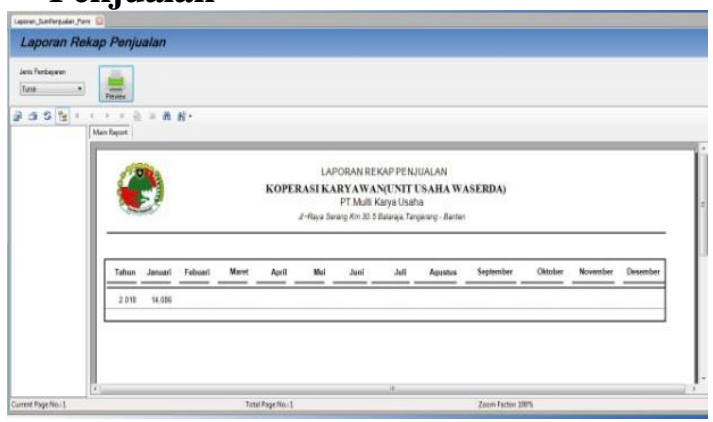

Gambar Tampilan Form Laporan Rekap Penjualan

\subsection{Tampilan Form Master Users}

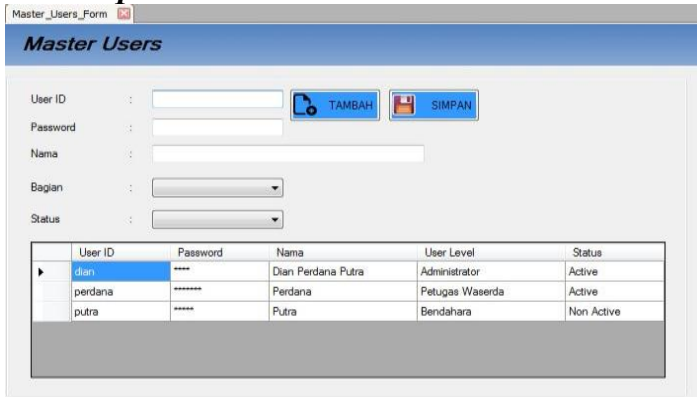

Gambar Tampilan Form Master Users

\subsection{Tampilan Form Permission Access}

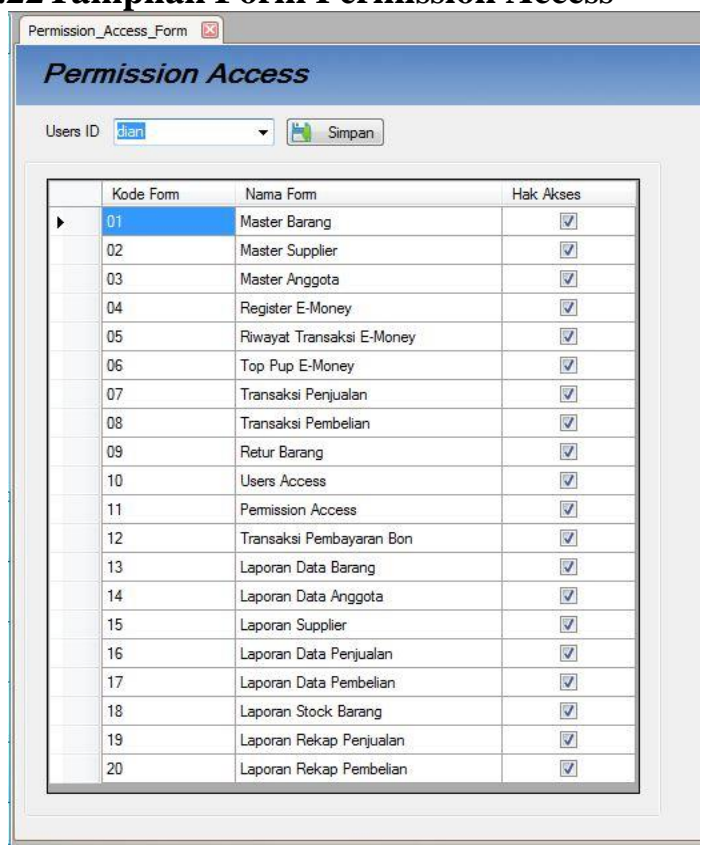

\section{Kesimpulan}

Berdasarkan uraian-uraian yang telah penulis paparkan pada bab-bab sebelumnya, maka penulis menarik kesimpulan sebagai berikut:

a. Dengan adanya sistem yang baru ini, antrean saat melakukan pembelian dapat dikurangi sehingga anggota koperasi sebagai pelanggan dapat dilayani dengan baik.

b. Dengan adanya sistem yang baru ini, informasi laporan stok barang yang tersedia dapat di akses dengan mudah pada aplikasi dan aplikasi dapat menampilkan secara real time.

c. Dengan adanya sistem yang baru ini, ketidaksuaian antara laporan pemasukan keuangan dan sisa stok dapat diatasi, karena aplikasi dapat menghitung dan mengeluarkan laporan secara otomatis.

d. Dengan adanya sistem yang baru ini, laporan rekap data keuangan dapat diakses dengan mudah pada aplikasi tanpa harus melalui proses yang panjang.

\section{Daftar Pustaka}

Afrianto, I., Maulana, H., \& Agustia, R. D. (2017, Febuari 22). Seminar Nasional Inovasi Teknologi UN PGRI Kediri. Model Transportasi Terpadu Kota Bandung Berbasis Radio Frequency Identification (RFID), 10.

Atmojo, O. P., Tung, L. U., \& Santoso, P. (2016, Maret). Pengembangan Mekanisme Pembayaran Pujasera (Food Court) Menggunakan Teknologi RFID yang Dilengkapi dengan PIN. Jurnal Teknik Elektro, 9(1), 8.

Fowler, M. (2004). UML Distilled. (T. P. ANDI, Trans.) Yogyakarta: Penerbit ANDI.

Krisna, O. N., Nurcahyawati, V., \& Soebijono, T. (2016). JSIKA. Rancang Bangun Aplikasi Penjualan Barang Pada Toko Kpri "Bahagia" Di Candi Sidoarjo, 5(12), 5.

Kushermanto, Y. B. (2017, Maret). Jurnal Informatika SIMANTIK. Penerapan Teknologi RFID Modul RC522 Berbasis Raspberry Pi B+, 1(2), 6.

Maryono. (2005). Media Informasi 2005, XIV(20). Dasar-Dasar Radio Frequency Identification (RFID),Teknologi Yang Berpengaruh Di Perpustakaan, 12.

Rosa, A. S., \& M.Shalahuddin. (2011). Modul Pembelajaran Rekayasa Perangkat Lunak. Bandung: Penerbit MODULA.

Sukerti, N. K. (2017, Agustus 10). Konferensi Nasional Sistem \& Informatika 2017 STMIK STIKOM Bali. Implementasi Sistem Informasi Penjualan Untuk Minimarket, 5.

WAHANA KOMPUTER. (2010). Shortcourse SQL Server 2008 Express. Semarang: CV. ANDI OFFSET (Penerbit ANDI). 